\title{
The Impact of Financial Literacy on Student Teachers' Saving Intention and Saving Behaviour
}

Umi Widyastuti

Usep Suhud

Ati Sumiati

Faculty of Economics, Universitas Negeri Jakarta, Jakarta 13220, Indonesia

Doi:10.5901/mjss.2016.v7n6p41

\section{Abstract}

One of the national agendas in Indonesia is delivering financial literacy towards its society. This movement was in response to a report that Indonesia was ranked as a country with the lowest financial literacy lever among other countries in the Asia-Pacific region. This study aims to investigate the impact of attitude, subjective norm, and financial literacy on saving intention and behaviour among teacher students in a public university in Jakarta, Indonesia. Teacher students are pre-service teachers who could promote financial literacy at schools in the future. Data was collected using an online survey. In total, there were 212 usable instruments and data was analysed using exploratory and confirmatory factor analysis. As a result, two hypotheses were rejected: financial literacy was insignificant to influence attitude towards saving and saving intention. Other results, financial literacy and saving intention significantly influenced saving behaviour. In addition, attitude and subjective norm significantly influenced saving intention. Implication for practice and future research are discussed.

Keywords: financial literacy, attitude towards saving, saving intention, saving behaviour, teacher students, confirmatory factor analysis

\section{Introduction}

Indonesia was ranked as the lowest financial illiterate in the Asia-Pacific region for years (Amirio, 2015). Therefore, financial literacy becomes a national strategy under the management of the Financial Service Authority (OJK-Otoritas Jasa Keuangan) as the formal institution that was pointed by the Indonesian government to take this responsibility (Subinarto, 2014). Furthermore, to increase the financial literacy level of Indonesians, OJK in cooperation with other parties, such as financial industry and higher education institutions, conducted a financial education (Subinarto, 2014). The main targets for this operation are students (elementary to high schools), housewives, and micro, small, and medium enterprises (Sulaiman, 2014). On the other hand, Wachira and Kihiu (2012) suggested that financial education should be also developed in higher level of education institutions.

Prior studies on financial literacy involved universities and colleges students both in developed countries, such as in the USA, Australia, and Israel (Beal \& Delpachitra, 2003; Jorgensen, 2007; Shahrabani, 2012) and developing countries, such as in Turkey, South Africa, Malaysia, and Indonesia (Akben-Selcuk, 2015; Nidar \& Bestari, 2012; Shambare \& Rugimbana, 2012). However, there is paucity of research on financial literacy involving teacher students, particularly in Indonesia.

Financial literacy is considered important for individuals as well as for communities. Studies mentioned that financial literacy would be a foundation to develop financial education. In Indonesia, since 2013, financial literacy has been inserted in the school curriculum as a strategy to increase financial literacy level (Sipahutar \& Wardhani, 2014).

While financial literacy is influenced by money attitude, retirement plan intention, level of education, faculty, personal income, knowledge from parents, parents income, and ownership of insurance factors (Nidar \& Bestari, 2012), on the other hand, financial literacy can influence attitude, saving intention, and saving behaviour.

Although some countries were not ranked as the lowest financial illiterate, in general, they found that their citizens lack of financial literacy, such as in the United States (Mandell \& Klein, 2009). Therefore, they feel continuously make efforts so that the level of financial literacy of this community can be increased gradually. In Brazil, according to Bruhn, de Souza Leão, Legovini, Marchetti, and Zia (2013) financial education programs was held at entire high schools.

Financial literacy has widely studied by researchers and they found that it has a positive impact on financial behaviour and saving intention (Lusardi, 2008; Mahdzan \& Tabiani, 2013). Although some studies reported a significant 
result of the impact of financial literacy, some other studies told differently, for example, financial literacy had no connection with accessibility to financial institution (Wachira \& Kihiu, 2012) or "those who took the course were no more financially literate than those who had not" (Mandell \& Klein, 2009, p. 1).

The objective of this study is to examine the impact of financial literacy, attitude towards saving, and subjective norm on saving intention and its implication on saving behaviour among teacher students at a public university in Jakarta. Attitude and subjective norm are two prominent variables included both in theory of reasoned action (TRA) and theory of planned behaviour (TPB) (Ajzen, 1991; Fishbein \& Ajzen, 1975). However, apparently between those theories, TPB might be the most employed in financial literacy studies, for example by Croy, Gerrans, and Speelman (2010) and K. Davis and Hustvedt (2012).

\section{Review of Literature}

\subsection{Research Framework and Hypotheses}

This study is addressed to explore the research framework as illustrated below. There are five variables including in the model: financial literacy, attitude towards saving, subjective norm, intention to saving, and saving behaviour.

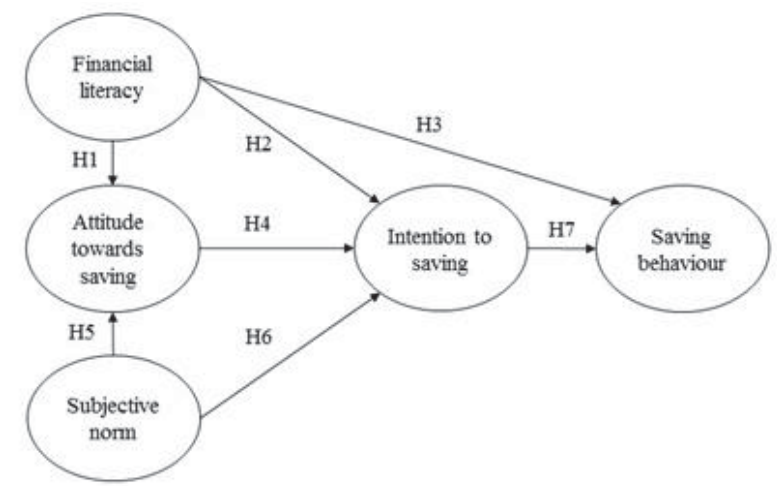

Figure 1. The proposed model

Besides, here are seven hypotheses to be tested as follows:

$\mathrm{H}_{1}$ - There is a significant impact of financial literacy on attitude towards saving

$\mathrm{H}_{2}$ - There is a significant impact of financial literacy on saving intention

$\mathrm{H}_{3}$ - There is a significant impact of financial literacy on saving behaviour

$\mathrm{H}_{4}$ - There is a significant impact of attitude towards behaviour on saving intention

$\mathrm{H}_{5}$ - There is a significant impact of subjective norm on attitude towards saving

$\mathrm{H}_{6}$ - There is a significant impact of subjective norm on saving intention

$\mathrm{H}_{7}$ - There is a significant impact of saving intention on saving behaviour

\subsection{Background of Theories}

\subsubsection{Financial Literacy}

Financial literacy is a set of ability to read, analyse, understand, manage, and communicate the financial terms and basic economic concepts that are used in personal financial decisions effectively (Kharchenko, 2011; Noctor, Stoney, \& Stradling, 1992; Servon \& Kaestner, 2008). According to Zait and Bertea (2015, p. 40), financial literacy consists of five dimensions: "financial knowledge, financial communication ability, ability to use financial knowledge for decision taking, real use of financial instruments (financial behaviour), and financial confidence". Furthermore, these scholars suggested that "for every dimension, the measures need to refer to at least four financial areas or fields: personal budgeting, savings, credits and investments; the health insurance aspects and pension issues should be treated within the 


\section{investments area".}

Some studies reported the impact of financial literacy on attitude towards saving, saving intention, and saving behaviour. College and university students in Malaysia were selected by Jamal, Ramlan, Karim, and Osman (2015) in their study. They employed variables including attitude towards saving and financial literacy to predict saving behaviour. They found that financial literacy had a significant impact on attitude towards saving as well as on saving behaviour. Badshah, Hakam, Khan, and Saud (2014) examined the link between financial literacy and short-term investment intention among 46 potential investors in Pakistan. Finding of this study verified that financial literacy significantly linked to intention to invest.

It is unarguable that financial literacy can also influence saving behaviour (Jamal et al., 2015; Thung, Kai, Nie, W., \& Tsen 2012). Additionally, Shafi (2014) identified four groups of determinant factors to influence investment behaviour, particularly on stock investment: social (influence of people's opinion and herding), psychological (cognitive bias, irrational thinking, confidence, get rich quick, and over-reaction), demographic (gender, age, income, and education), and economic.

Furthermore, Vijaya (2014) mentioned that there are six groups of factors influencing individual behavioural investment. These are cognitive (confidence, information availability, anchoring), emotional (regret aversion, loss aversion, endowment bias, mental accounting), herding (buying and selling decisions of other investors, choice of stock to trade of other investors, and volume of stock to trade of other investors), market (price changes, market information, past trends of stock, fundamentals of underlying stock, customer preferences, and over reactions to price changes)), demographic (age, gender, income, marital status, education, and occupation), and contextual factors (personal and financial needs, information, firm image, neutral information, and advocate recommendations).

\subsubsection{Subjective Norm}

Subjective norm is a support or pressure towards a person from people he or she considers important and respected, for example, a parent, spouse, friend, and teacher (Ajzen, 1991). In the theory of reasoned action and theory of planned behaviour (Ajzen, 1991; Ajzen \& Fishbein, 1980), subjective norm is included to be used to predict behavioural intention. While there is a paucity of study concerning on the impact of subjective norms on attitude towards saving, some studies demonstrated that subjective norm has an impact on saving intention (Croy et al., 2010; Cuong \& Jian, 2014; PascualEzama, Scandroglio, \& Liaño, 2014; Sondari \& Sudarsono, 2015).

Sondari and Sudarsono (2015) involved 359 servant civils in Indonesia. As a result, attitude and subjective norm significantly influenced intention to invest. Similar findings were showed by Cuong and Jian (2014). In total, there were 472 individual investors included in the study. These scholars demonstrated that attitude toward the behaviour and subjective norm had a positive and significant impact on intention to invest. In addition, these scholars revealed that there was a significant link between subjective norm and attitude.

Another study conducted by Pascual-Ezama et al. (2014) included 127 individual investors from the Spanish stock exchange. This study showed that attitude toward behaviour and subjective norm had a positive and significant impact on intention to invest. Furthermore, taking place in Australia, Croy et al. (2010) studied the intention of retirement to saving. The study exposed significant links between attitude and intention as well as the impact of subjective norm and intention.

\subsubsection{Saving Intention}

Behavioural intention is a stage that might lead to an action. Studies in consumer behaviour primarily examining factors that influence behavioural intention as well as factual behaviour (F. D. Davis, 1989; Fishbein \& Ajzen, 1975). Rodermund (2012) employed theory of reasoned action and theory of planned behaviour to investigate saving behaviour. This study showed that significantly saving intention influenced actual behaviour. Some other studies also reported that saving intention can influence saving behaviour (Cuong \& Jian, 2014; Kisaka, 2014; Pascual-Ezama et al., 2014; Sondari \& Sudarsono, 2015).

\section{Methods}

\subsection{Participants}

This study involved teacher students at a public university in Jakarta. The authors chose this sample category as teacher students are a pre-service teacher who could promote financial literacy in schools in the future. 
In total, there were 212 respondents participated in this study. Predominant of them were females (170). As mentioned earlier, all respondents were teacher students. Thirty of them had a part-time job and five of them had a fulltime job. Furthermore, predominant respondents were singles (211) and only one of them was married. Respondents aged between 17 and 25 years old. Most of them were 19 years old (68), followed by 20 years old (20). When respondents were asked their dwelling status, 155 (73.1\%) of them stated that they lived with their parents, 19 (9\%) lived with other family members (sisters/brothers/relatives/uncles/aunties/grandfathers/mothers), while others lived in a dorm, pesantren (an Islamic-based dorm), rent a room, and others.

\subsection{Instrument Development}

Six indicators taken from Chudzian, Aniola-Mikolajczak, and Pataraia (2015) were adapted to measure attitude towards saving. Furthermore, to measure subjective saving norm and saving intention, and saving behaviour, the authors adapted indicators taken from (Magendans, 2014), and USAID and The World Bank (2011). In addition, indicators from Gachango (2014) were adapted to measure financial literacy.

\section{Data Analysis and Findings}

\subsection{Exploratory Factor Analysis}

\subsubsection{Financial Literacy}

Eight indicators of financial literacy survive and form two dimensions: extrinsic factors (four indicators) with a Cronbach's alpha of 0.829 and intrinsic factors (four indicators) with a Cronbach's alpha of 0.849 .

Table. 1. Exploratory factor analysis result of financial literacy

\begin{tabular}{|clc|}
\hline 1 & Extrinsic factors & $\boldsymbol{\alpha}=\mathbf{0 . 8 2 9}$ \\
\hline FiL7 & I check the accuracy of transactions then file them & 0.966 \\
FiL5 & I do regularly check my bank statements for inconsistencies & 0.859 \\
FiL6 & I balance my check book carefully & 0.859 \\
FiL8 & I am/ will be prepared to manage my finances upon retirement & 0.479 \\
\hline $\mathbf{2}$ & Intrinsic factors & $\boldsymbol{\alpha}=\mathbf{0 . 8 4 9}$ \\
\hline FiL2 & I can use combinations of skills, resources and knowledge to make financial decisions. & -0.921 \\
FiL3 & I can make informed effective financial choices & -0.855 \\
FiL1 & I have the ability to discern financial choices and discuss financial issues without discomfort. & -0.844 \\
FiL4 & I understand financial terms and concepts & -0.580 \\
\hline
\end{tabular}

\subsubsection{Attitude Towards Saving}

Seven indicators of attitude towards saving retain with two dimensions produced: favourable attitude (five indicators) with a Cronbach's alpha of 0.492 , and unfavourable attitude (two indicators) with a Cronbach's alpha of 0.405 . Although these dimensions are considered unreliable, the authors retained them for further calculation.

Table. 2. Exploratory factor analysis result of attitude toward saving

\begin{tabular}{|clc|}
\hline & Favourable attitude & $\mathbf{\alpha}=\mathbf{0 . 4 9 2}$ \\
\hline At4 & Saving gives me a sense of security & 0.722 \\
At6 & Saving means a constant sacrifice and parsimony & -0.647 \\
At2 & I think saving money is trendy nowadays & 0.610 \\
At5 & Saving is a matter of good organisation & 0.492 \\
At1 & I think saving money makes me a better person & 0.453 \\
\hline & Unfavourable attitude & $\mathbf{\alpha}=\mathbf{0 . 4 0 5}$ \\
\hline At7 & Saving means parsimony & 0.807 \\
At3 & Saving is for poor people. & 0.660 \\
\hline
\end{tabular}




\subsubsection{Subjective Norm}

All six indicators of subjective norm retain with a Cronbach's alpha of 0.862 and factor loadings ranging from 0.601 to 0.868 .

Table. 3. Exploratory factor analysis result of subjective norm

\begin{tabular}{|llc|}
\hline & $\mathbf{\alpha = 0 . 8 6 2}$ \\
\hline Sn2 I think that people who I consider important or who's opinion I respect think it's important that I save regularly & 0.868 \\
Sn3 I think that people who I consider important or who's opinion I respect expect that I save regularly & 0.859 \\
Sn4 I think that people who I consider important or who's opinion I respect view regularly saving positively & 0.807 \\
Sn1 I think that people who I consider important or who's opinion I respect save regularly themselves & 0.801 \\
Sn5 & My friends consider it important to save money every month for unexpected expenditures \\
Sn6 My parents consider it important to save money every month for unexpected expenditures & 0.653 \\
\hline \multicolumn{2}{|c}{ Cronbach's alpha } & 0.601 \\
\hline
\end{tabular}

\subsubsection{Saving Intention}

Saving intention has three dimensions: saving for a purpose (five indicators) with a Cronbach's alpha of 0.701; saving for a risk (four indicators) with a Cronbach's alpha of 0.652 ; and saving barriers (three indicators) with a Cronbach's alpha of 0.704 .

Table. 4. Exploratory factor analysis result of saving intention

\begin{tabular}{|clc|}
\hline 1 & Saving for a purpose & $\alpha=0.701$ \\
\hline Si3 & I want to save money so that I'm prepared for unexpected expenditures & 0.792 \\
Si6 & I intent to save money for unexpected expenditures & 0.738 \\
Si7 & I expect to save money in the coming months & 0.618 \\
Si12 & I primarily save to achieve my future goals & 0.483 \\
Si13 & I see money as a means to achieve important goals in the long run & 0.477 \\
\hline $\mathbf{2}$ & Saving for a risk & $\mathbf{\alpha}=\mathbf{0 . 6 5 2}$ \\
\hline Sig & If there is a large chance on profit, I'm willing to take even large risks* & 0.866 \\
Si8 & If I want to achieve a lot of profit, then I intend to take large risks* & 0.780 \\
Si11 & To achieve something in life you need to be willing to take risks* & 0.740 \\
Si10 & I occasionally take financial risks for fun or to satisfy curiosity* & 0.410 \\
\hline 3 & Saving barriers & $\alpha=0.704$ \\
\hline Si2 & I consider saving to be an unnecessary activity* & -0.847 \\
Si1 & I consider saving to be a boring activity* & -0.834 \\
Si4 & I don't consider it necessary to save money in the near future* & -0.684 \\
\hline
\end{tabular}

Note: indicators with an * was transformed before further analysis

\subsubsection{Saving Behaviour}

Eight indicators of saving behaviour survived during exploratory factor analysis. These indicators formed two dimensions: investing behaviour (six indicators) with a Cronbach's alpha of 0.790 and spending behaviour (two indicators) with a Cronbach's alpha of 0.619 .

Table. 5. Exploratory factor analysis of saving behaviour

\begin{tabular}{|clc|}
\hline 1 & Investing behaviour & $\boldsymbol{\alpha}=\mathbf{0 . 7 9 0}$ \\
\hline Sb3 & I have saved money for unexpected expenditures & 0.780 \\
Sb2 & In the past six months, I have frequently saved money & 0.768 \\
Sb1 & Besides the money I have already saved, I still save regularly & 0.761 \\
Sb4 & I also save money when I don't have a real saving goal & 0.727 \\
Sb8 & I try to save something and spend the rest on daily needs & 0.541 \\
Sb7 & I spend money on daily needs and save the rest & 0.528 \\
\hline $\mathbf{2}$ & Spending behaviour & $\alpha=\mathbf{0 . 6 1 9}$ \\
\hline Sb6 & I spend all the money and do not save & 0.814 \\
Sb5 & I did not save money in any of the past 12 months* & 0.810 \\
\hline
\end{tabular}

Note: indicators with an * was transformed before further analysis 


\subsubsection{Confirmatory Factor Analysis}

The research framework owns a fitted model with probability, CMIN/DF, CFI, and RMSEA scores of $0.355,1.040,0.996$, and 0.014 respectively (see the figure below).

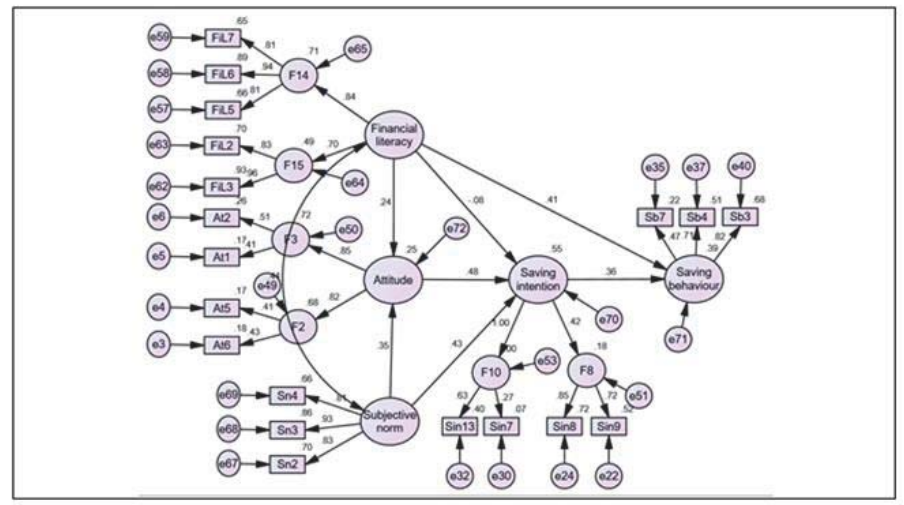

Figure 2. Confirmatory factor analysis result

As documented in the table below, financial literacy fails to be significant in influencing attitude towards saving and saving intention. These paths have C.R. scores of 1.440 and -0.577 respectively. Therefore, $\mathrm{H}_{1}$ and $\mathrm{H}_{2}$ are rejected. However this finding is significant with the finding carried out by Jamal et al. (2015) On the other hand, financial literacy significantly influences saving behaviour with a C.R. score of 3.191. Therefore, $\mathrm{H}_{3}$ is accepted. This finding support a study reported by Jamal et al. (2015) and Thung et al. (2012).

Furthermore, Attitude has a significant influence on saving intention with a C.R. score of 3.695. Therefore, $\mathrm{H}_{4}$ is accepted. this finding support studies conducted by Sondari and Sudarsono (2015), Pascual-Ezama et al. (2014) and Cuong and Jian (2014).

Subjective norm significantly influences attitude towards saving and saving intention with C.R. score of 2.099 and 2.275 respectively. Therefore, $\mathrm{H}_{5}$ and $\mathrm{H}_{6}$ are accepted. Prior studies conducted by Croy et al. (2010), Sondari and Sudarsono (2015), Pascual-Ezama et al. (2014), and Cuong and Jian (2014) support $\mathrm{H}_{6} . \mathrm{H}_{7}$ predicted the impact of saving intention on saving behaviour. It was also accepted with a C.R. score of 3.695. This finding is significant with studies conducted by Cuong and Jian (2014), Pascual-Ezama et al. (2014), and Sondari and Sudarsono (2015).

Table. 6. Summary of hypotheses testing

\begin{tabular}{|llllll|}
\hline & Paths & & & C.R. & Results \\
\hline $\mathrm{H}_{1}$ & Financial literacy & $\mathbf{M}$ & Attitude & 1.440 & Rejected \\
$\mathrm{H}_{2}$ & Financial literacy & $\mathbf{7}$ & Saving intention & -0.577 & Rejected \\
$\mathrm{H}_{3}$ & Financial literacy & $\mathbf{M}$ & Saving behaviour & 3.191 & Accepted \\
$\mathrm{H}_{4}$ & Attitude & $\mathbf{7}$ & Saving intention & 3.695 & Accepted \\
$\mathrm{H}_{5}$ & Subjective norm & $\mathbf{M}$ & Attitude & 2.099 & Accepted \\
$\mathrm{H}_{6}$ & Subjective norm & $\mathbf{\rightarrow}$ & Saving intention & 2.275 & Accepted \\
$\mathrm{H}_{7}$ & Saving intention & $\mathbf{\rightarrow}$ & Saving behaviour & 3.695 & Accepted \\
\hline
\end{tabular}

\section{Summary}

This study aims to measure the impact of financial literacy and subjective norm on attitude towards saving, saving intention, and saving behaviour of teacher students in Indonesia. In total there were seven hypotheses to be examined. Two hypotheses were rejected including the impact of financial literacy on attitude towards saving and saving intention.

On the other hand, five other hypotheses were accepted. Financial literacy significantly influenced saving 
behaviour and Saving behaviour was significantly influenced by financial literacy, saving intention, and subjective norm while saving intention was significantly influenced by attitude and subjective norm. the last, attitude towards saving was significantly influenced by subjective norm.

This study was designed to include participants from various faculties but in fact, predominant respondents were from the Faculty of Economics. Naturally of a faculty of economics, respondents obtained financial literacy from various lecture subjects, such as Banking, Insurance, and Finance Management. On the other hand, respondents from other faculties, such as Languages and Arts, Math and Natural Sciences, and Technique Faculties, did not received these kind of subjects. A recommendation of future study is to conduct a study by comparing participants from various setting of faculties as well as to distinguish respondents based on gender. While this study included only teacher students, future study may invite regular students too.

\section{References}

Ajzen, I. (1991). The theory of planned behaviour. Organizational Behaviour and Human Decision Processes, 50, 179-211.

Ajzen, I., \& Fishbein, M. . (1980). Understanding attitudes and predicting social behaviour. New Jersey: Prentice-Hall, Inc.

Akben-Selcuk, E. (2015). Factors influencing college students' financial behaviors in Turkey: Evidence from a national survey. International Journal of Economics and Finance, 7(6), 87.

Amirio, D. (2015). RI's financial literacy remains among lowest in Asia. Retrieved from The Jakarta Post website: http://www.thejakarta post.com/news/2015/09/04/ri-s-financial-literacy-remains-among-lowest-asia.html

Badshah, W., Hakam, U., Khan, A. S., \& Saud, S. (2014). Factors fffecting short-term investment intensions of stock investors in Pakistan. Management and Administrative Sciences Review, 3(3), 464-469.

Beal, D. J., \& Delpachitra, S. B. (2003). Financial literacy among Australian university students. Economic Papers: A Journal of Applied Economics and Policy, 22(1), 65-78.

Bruhn, M., de Souza Leão, L., Legovini, A., Marchetti, R., \& Zia, B. (2013). The impact of high school financial education: experimental evidence from Brazil. World Bank Policy Research Working Paper(6723).

Chudzian, J., Aniola-Mikolajczak, P., \& Pataraia, L. (2015). Motives and attitudes for saving among young Georgians. Economics \& Sociology, 8(1), 165.

Croy, G., Gerrans, P., \& Speelman, C. (2010). The role and relevance of domain knowledge, perceptions of planning importance, and risk tolerance in predicting savings intentions. Journal of Economic Psychology, 31(6), 860-871.

Cuong, P. K., \& Jian, Z. (2014). Factors influencing individual investors' behavior: An empirical study of the Vietnamese stock market. American Journal of Business and Management, 3(2), 77-94.

Davis, F. D. (1989). Perceived usefulness, perceived ease of use, and user acceptance of information technology. MIS quarterly, 319340.

Davis, K., \& Hustvedt, G. (2012). It'sa matter of control: Saving for retirement. International Review of Social Sciences and Humanities, 3(2), 248-261.

Fishbein, M., \& Ajzen, I. (1975). Belief, attitude, intention and behaviour: An introduction to theory and research: Addison-Wesley.

Gachango, D. M. (2014). Effect of financial literacy on personal financial management practices: A case of employees in finance and banking institutions in Kenya. (Master ), University of Nairobi, Nairobi.

Jamal, A. A. A., Ramlan, W. K., Karim, M. R. A., \& Osman, Z. (2015). The effects of social influence and financial literacy on savings behavior: A study on students of higher learning institutions in Kota Kinabalu, Sabah. International Journal of Business and Social Science 6(11), 110-119.

Jorgensen, B. L. (2007). Financial literacy of college students: Parental and peer influences. (Master), Virginia Polytechnic Institute and State University, Virnidia.

Kharchenko, O. (2011). Financial literacy in Ukraine: Determinants and implications for saving behavior. (Master), Kyiv School of Economics, Kiev.

Kisaka, S. E. (2014). The impact of attitudes towards saving, borrowing and investment on the capital accumulation process in Kenya: An application of the theory of planned behavior. Research Journal of Finance and Accounting, 5(9), 140-151.

Lusardi, A. (2008). Household saving behavior: The role of financial literacy, information, and financial education programs (pp. 1-44): National Bureau of Economic Research.

Magendans, J. A. (2014). The cost of self-protective measures: psychological predictors of saving money for a financial buffer. (Master), University of Twente, Twente.

Mahdzan, N. S., \& Tabiani, S. (2013). The impact of financial literacy on individual saving: an exploratory study in the Malaysian context. Transformations in Business \& Economics, 12(1), 41-55.

Mandell, L., \& Klein, L. S. (2009). The impact of financial literacy education on subsequent financial behavior. Journal of Financial Counseling and Planning, 20(1), 15-24.

Nidar, S. R., \& Bestari, S. (2012). Personal financial literacy among university students (Case study at Padjadjaran University students, Bandung, Indonesia). World Journal of Social Sciences, 2(4), 162-171.

Noctor, M., Stoney, S., \& Stradling, R. (1992). Financial literacy: A discussion of concepts and competences of financial literacy and opportunities for its introduction into young people's learning. National Foundation for Educational Research. 
Pascual-Ezama, D., Scandroglio, B., \& Liaño, B. G-G. d. (2014). Can we predict individual investors' behavior in stock markets? A psychological approach. Universitas Psychologica, 13(1), 25-35.

Rodermund, R. H. (2012). Examining the savings habits of individuals with present-fatalistic time perspectives using the theory of planned behavior. Retrieved July 22, 2016, from Academy of Financial Services http://www.academyfinancial.org/wpcontent/uploads/2013/10/F2-Rodermund.pdf

Servon, L. J., \& Kaestner, R. (2008). Consumer financial literacy and the impact of online banking on the financial behavior of lowerincome bank customers. Journal of Consumer Affairs, 42(2), 271-305.

Shafi, M. (2014). Determinants influencing individual investor behavior in stock market: A cross country research survey. Arabian Journal of Business and Management Review, 2(1), 60-71.

Shahrabani, S. . (2012). The effect of financial literacy and emotions on intent to control personal budget: A study among Israeli college students. International Journal of Economics and Finance, 4(9), 156-163.

Shambare, R., \& Rugimbana, R. (2012). Financial literacy among the educated: An exploratory study of selected university students in South Africa. Thunderbird International Business Review, 54(4), 581-590.

Sipahutar, T. , \& Wardhani, D. A. (2014). OJK targets improved financial literacy rate. Retrieved from The Jakarta Post website: http://www.thejakartapost.com/news/2014/11/27/ojk-targets-improved-financial-literacy-rate.html

Sondari, M. C. , \& Sudarsono, R. (2015). Using theory of planned behavior in predicting intention to invest: Case of Indonesia. International Academic ResearchJournal of Business and Technology, 1(2), 137-141.

Subinarto, D. (2014). Improving financial literacy. Retrieved from The Jakarta Post website: http://www.thejakartapost.com/news/ 2014/02/07/improving-financial-literacy.html

Sulaiman, F. . (2014). OJK: Indonesias' financial literacy level vey low (in Bahasa Indonesia). Retrieved from Warta Ekonomi website: http://wartaekonomi.co.id/read/2014/04/16/27812/ojk--tingkat-melek-keuangan-masyarakat-indonesia-sangat-rendah.html

Thung, C. M., Kai, C. Y., Nie, F. S., W., Chiun. L., \& Tsen , T. C. (2012). Determinants of saving behaviour among the university students in Malaysia. (Bachelor), Universitu Tunku Abdul Rahman, Kampar.

USAID, \& The World Bank. (2011). Comprehensive report for the World Bank: "Financial literacy and consumer awareness survey in the West Bank and Gaza.

Vijaya, E. (2014). Influential factors on investment behaviour of individual investors: A review of empirical evidences from various countries. International Research Journal of Management and Commerce, 1(5), 28-38.

Wachira, M. I., \& Kihiu, E. N. (2012). Impact of financial literacy on access to financial services in Kenya. International Journal of Business and Social Science, 3(19), 42-50.

Zait, A., \& Bertea, P. E. (2015). Financial literacy - Conceptual definition and proposed approach for a measurement instrument. The Journal of Accounting and Management, 4(3), 37-42. 